\title{
POLISH - JUST LIKE “ANOTHER ENGLISH”: PERCEPTIONS OF TRANSLANGUAGING AND OTHER BILINGUAL PRACTICES IN ENGLISH AND POLISH FL CLASSROOMS IN TAIWANESE UNIVERSITIES
}

Keywords: translanguaging, bilingualism, multilingualism, Taiwan, EFL, Polish FL

\begin{abstract}
The purpose of this paper is to analyse how English and Polish FL learners in Taiwan perceive translanguaging and other bilingual practices implemented in university classrooms. Around $70 \%$ of the questionnaire respondents were positive about monolingual instruction, however, only $7 \%$ though it should prevail. More than $90 \%$ accepted the usage of more than one language in class. Among the main benefits of single-language instruction, efficiency of the learning process and promoting one's listening and speaking skills were mentioned. Deeper understanding and easier self-expression were seen as the main benefits of the bilingual approach. Different in-class activities that should be carried out in the target/native language have also been listed. Generally, the participants preferred mixed-language instruction, although they were aware of the benefits of the monolingual approach. Thus, teachers may consider including more diversified techniques to answer to the varying needs of Taiwanese EFL and PFL learners.
\end{abstract}

\section{INTRODUCTION}

A growing body of research has presented a wide range of applications of translanguaging and other bilingual practices in the context of FL pedagogy. Using Otheguy and Garcia's (2015) research as a theoretical framework, this paper aims to examine more closely how they are deployed and perceived in FL classes in Taiwanese university settings.

One may wonder whether it is legitimate to examine a particular group of language learners separately based mainly on their national identity. Are Taiwanese

*natalia.tsai@onet.eu, Hsin Wu University, College of Hospitality and Tourism, The Department of Applied English, No. 101, Sec. 1, Fenliao Rd, New Taipei City, Linkou District 24452, Taiwan. 
students somehow different from their counterparts from other places? As pointed out by Lai (2009, p. 271), cultural setting and national origin do have an impact on individual learning practices and preferences, given the education system and the experiences that may be common for the students. For example, Taiwanese are more than likely to have started their EFL adventure in kindergarten and acquired the language through nursery rhymes and games, just to get enrolled into language courses in private cramming schools called buxiban. They are used to memorizing vocabulary lists, applying grammar rules, and taking multiple-choice tests, but many of them may lack experience in speaking.

\section{LITERATURE REVIEW}

The word translanguaging, referring to "the ability of multilingual speakers to shuttle between languages, treating the diverse languages that form their repertoire as an integrated system" (Canagarajah 2011, p. 401) comes from the Welsh trawsiethu. Originally coined by Cen Williams in 1994 to denote the "specific model of bilingual education which involves giving input in one language and producing output in another language" (Holmen 2019, p. 49), i.e. the situation in which Welsh educators were trying to revitalize their own language instead of teaching only in English. Since then, the term has been widely employed by scholars in the Anglo-Saxon tradition (McKinney 2017, p. 24). Garcia and Wei (2014) have defined translanguaging as an "approach to the use of language, bilingualism, and the education of bilinguals that considers the language practices of bilinguals not as two autonomous language systems as has traditionally been the case, but as one linguistic repertoire with features that have been societally constructed as belonging to two separate languages." Put briefly, translanguaging may be seen as "the linguistic practices of speakers labeled as bilingual or multilingual", as suggested by Otheguy etal. $(2015$, p. 282). In its strong version, it argues that speakers rely on their own resources of lexical and structural features instead of using named languages (Willey, Garcia 2016, p. 58).

Traditionally, languages used to be (and sometimes still are) seen as artificial conventions that could be taught, tested, and hierarchically labelled as L1, L2, and L3, but they were somewhat superior and external to the learner. In other words, one could learn them, but perhaps not own them, for they would belong to the communities of natives speakers (Otheguy et al., 2015, label them as named languages). Besides, individual linguistic resources were sometimes perceived as separate bins from which they should draw when expressing themselves (with the term code switching to denote the situation in which the mixing of resources would take place). To reduce the risk of "cross-contamination", they were to remain 
rigidly apart from each other: a practice widely known as two solitudes (Anton et al., 2016, p. 30). Any acts of mixing were institutionally discouraged (Creese, Blackledge 2010, p. 105).

With the development of translanguaging theory and the shift of power to the more personal level, more respect is being paid to cultural and linguistic background and the practices one may have been immersed in. Learner-centredness takes the place of traditional instruction (Garcia, Sylvan 2011, p. 396). As a result, the overall picture of a language learner is becoming far more dynamic than before. $\mathrm{He} / \mathrm{she}$ is now seen as operating one linguistic system, with the later language understood as a set of lexical and structural features that add to an individual's repertoire and are deployed to enable communication, and not as a distinct code, as stated by Otheguy et al. (2015, pp. 282, 286).

Given that there are 7,117 living languages spoken worldwide, as recently estimated by Eberhard (Ethnologue: Languages... 2020), and 195 countries, ${ }^{1}$ numerous contemporary societies can hardly be regarded as monolingual. ${ }^{2}$ The validity of pure distinctions can be then questioned. As suggested by the proponents of multimodality, we are constantly exposed to a great variety of semiotic symbols, both audio and visual, so that it is becoming less common for a message to be expressed in a single code. The traditional distinction between speech and writing may be less common nowadays, for we get showered by multiple images, gestures, and means of expression, (Cenoz, Gorter 2011a, p. 340), thus the need to go beyond the old clear-cut educational paradigms and "bridge the gap between out-of-school multilingual and multimodal practices and formal school practices" (Cenoz, Gorter 2011b, p. 367). In numerous settings (including workplaces), individuals are more than likely to function in highly diversified contexts, often receiving input in one language and producing output in another. In this situation, there is no need for a classroom to remain in opposition to this natural development (Cenoz, Gorter 2011a, p. 443). As the Dynamic Systems Theory assumes, language is not a fixed, ready-made code to be applied once you know it. On the contrary, SLA appears to reflect the changing nature of human interactions and the multiplicity of the means underlying each communication act (Cenoz, Gorter 2011b, p. 357). Thus, the need appears for a new paradigm of "heteroglossic conceptualizations", as it is put by Garcia and Sylvan (2011, p. 385).

Nowadays, most learners are actually bilingual and it is necessary to honour the linguistic diversity that students bring to class and to create more space for bilingual practices with translanguaging among them, with respect to the unique ecosystem of particular settings (Creese, Blackledge 2010, p. 103). For Rader (2017,

${ }^{1}$ With Taiwan not being included in this total count, because the United Nations does not recognize it and considers it represented by the People's Republic of China with the capital in Beijing.

${ }^{2}$ As recently estimated by Eberhard et al (Ethnologue: Languages... 2020), there are 7,117 living languages spoken worldwide. 
p. 44) the practice comes naturally and is a matter of justice, so that discrimination of bilingual students may be eliminated from educational settings. The isolation of the target language has traditionally served the purpose of maximizing exposure and eliminating interferences (Busse et al 2019, p. 4). However, for some scholars, with Garcia and Sylvan among them (2011, p. 398), non-mixing, teacher-centred instruction is simply an anachronism: "Clearly, monolingual education is no longer relevant in our globalized world." As Canagarajah (2011, p. 401) puts it, the phenomenon occurs naturally and the acts of translanguaging may occur unbidden, without teachers' implementation. Students should be actively encouraged to develop multilingual literacy and fluidity, since the old "one language at a time" exclusive curriculum actually doubles the risk of deprivation and may be seen as "linguistically oppressive" (Woodley 2016, p. 572).

\section{MULTILINGUALISM IN TAIWAN}

The sociolinguistic profile of Taiwan with its current population of 23,596,493 ${ }^{3}$ is highly diversified (Price 2019). Basically, there are 16 indigenous Austronesian Formosan languages along with the Sinitic languages brought by Chinese immigrants at different stages of the expansion: Mandarin (Chinese), Hoklo (also called Hokkien or simply Taiwanese), and Hakka. Multilingualism can be experienced at many levels: from the press, and product labels, to road signs and public transport. In most situations, English is enough to communicate, especially in offices, hospitals, tourist attractions, and department stores. It is worth mentioning, however, that all overseas guests are somehow expected to demonstrate a high degree of fluency in it. In the metro system, announcements will be provided in four languages, including English, to respect the needs of foreign visitors and residents, who otherwise could feel excluded. On some buses, especially on the routes connecting the main tourists spots, information will be displayed also in Japanese and Korean.

Mandarin (often simply called Chinese), maintains its status as the dominant language, deployed for official purposes, in education, as well as in the media. It is estimated to be used in $83.5 \%$ of households. For comparison, only $1.4 \%$ of the citizens declared speaking indigenous languages at home. Taiwanese is used by $81.9 \%$ of people, in some areas even by $95 \%$. Repressed by the Kuomintang after 1949, but recently supported by the leading Democratic Progressive Party, Hokkien is taught in schools at the elementary level. Still, senior citizens are believed

${ }^{3}$ As of March 2020 (as estimated by the National Statistics government bureau, https://eng.stat. gov.tw/point.asp?index $=9$ ). Around $90 \%$ of the population identify themselves as Taiwanese. One quarter of the citizens aged 15 or higher is estimated to have obtained a university degree. 
to be more fluent in it than the young. It is not uncommon for children to share only little of the language with their grandparents, which is often the case if the parents do not hold Taiwanese in high regard and emphasize Chinese and English instead. Hoklo may often be heard on the street or in some other public places, like markets or cafés, depending on the area. Hakka, in turn, is spoken by $6.6 \%$ of the population, although a Hakka ethnic background has been declared by $15 \%$ of the overall population. It is widely spoken in counties like Hsinchu or Miaoli. Cross--border marriage migration, a phenomenon observed since the 1990s, resulted in bringing in Vietnamese, Tagalog, and Cambodian, which are languages rather looked down upon. ${ }^{4}$ The so-called foreign wives/mothers from these linguistic backgrounds have rather been discouraged from passing their heritage on to their children (Price 2019, p. XVI).

Put briefly, it is fair to estimate that most Taiwanese are at least bilingual. As such, they often need to switch between different codes of communication if they want to adjust to the particular communication context, be it a private setting or a public discourse (Anton et al. 2016, p. 30).

\subsection{EFL EDUCATION IN TAIWAN}

There is great pressure among students to reach a high EFL proficiency level. Many of them have English names that are given to them at birth or at the early stages of education. It becomes imperative to demonstrate fluency, especially in conversation, and reach the native-speaker level of proficiency (Price 2014), a goal that may seem somewhat unrealistic and romanticized for an outsider observer. ${ }^{5}$ As noted by Cenoz and Gorter, (2011a, p. 340), such ambitious plans often create "a feeling of failure and incompleteness". It is not uncommon for the Taiwanese to perceive English as highly valued capital, a gatekeeper enabling an individual to compete on the job market, both locally and internationally, and, in the global scale, as a means to strengthen the international position of Taiwan (Price 2019, p. 199). EFL is taught from the pre-school level (and in some extreme

\footnotetext{
${ }^{4}$ International marriage is a profit-oriented practice of matching potential spouses from Taiwan and some developing Asian countries (Wang, Chang 2002). Blue-collar men from Taiwan decide to marry a woman from countries such as Vietnam, Thailand, the Philippines and Indonesia. In the peak year, one third of Taiwanese marriages involved an overseas spouse. Many of the so-called foreign wives, however, are said to be facing discrimination, both in Taiwan and their homeland. Frequent acts of domestic violence are another issue.

${ }^{5}$ The concept of a native speaker provides a measurement standard for one's linguistic competence. To be fluent in a target language is often seen as equal to achieving a NS level. To be bilingual means to be as fluent in each of the languages as a native speaker could be (Cenoz, Gorter 2011b, p. 357).
} 
cases from the pre-natal one), often by commercial institutions, like the so-called cramming schools (locally called buxiban) and private kindergartens, advertising their programmes as bilingual or international. Put simply, in public opinion, international equals 'high-grade' and 'prestigious', regardless of the actual level. The institutions in question often hire overseas (preferably white, especially blond) instructors, who can encourage the pupils to freely interact in English and use it as the main or only language of instruction. Parents often request a foreign teacher, demonstrating their willingness to pay a higher tuition fee than would be the case with a local lecturer of equal or even higher qualifications. Some of them boast that their child is more fluent in English than in Chinese. It is worth noticing that there is a certain degree of discrepancy between the privileged areas and the disadvantaged ones. The north, with the capital, Taipei, is said to offer much easier access to English education (ibid.)

\subsection{POLISH LANGUAGE IN TAIWAN}

Polish language in Taiwan is taught at several universities, usually as an elective course at the departments of Slavic or Russian studies, as is the case in the study described below.

\section{METHODOLOGY}

In order to better understand how Taiwanese English and Polish learners perceive translanguaging and how bilingual discursive practices may be utilized in the local didactic context, two types of questionnaires were distributed, tailored to the needs of both groups.

\subsection{PARTICIPANT DESCRIPTION}

The questionnaire respondents, 105 people in total, were college and university students enrolled in language courses in two universities in northern Taiwan; one of them public and the other one private. Except for two individuals who studied statistics and computer science, all of them majored in foreign languages. The ages of the participants ranged from 17 to 23 years old. Their linguistic repertoires were diverse, both in terms of the mother tongue and educational background. 
When asked about the languages spoken at home in everyday communication with their parents, $68 \%$ declared they use Chinese, 19\% Taiwanese, 2\% Hakka, and the remaining $12.8 \%$ Chinese along with other languages, including English, Tagalog (spoken in the Philippines), and Korean.

Among those who still had grandparents, $35 \%$ used Chinese to communicate with them, $35 \%$ Chinese and Taiwanese, $20 \%$ only Taiwanese, $4.1 \%$ Chinese and Hakka (used in Taiwan by people of Hakka ancestry), 4.1\% Chinese and some other languages, including Taiwanese and Hakka together, Tagalog, and some local dialects (unspecified by the respondents). Hakka alone was used by the remaining $2.8 \%$.

The students were asked to evaluate their own proficiency level in the language used for communication at home or with the grandparents, if other than Chinese. The dominating majority considered themselves fluent in it, with one third of them feeling quite confident about their own language ability, $45 \%$ somewhere in the middle and around one-fifth not that fluent.

Another aspect was the number of foreign languages they had learned. Almost half of the participants $(47.3 \%)$ had learned two foreign languages; in one third of the cases the additional language, after EFL, was Japanese. Three out of ten $(31.1 \%)$ declared having learned only English, $18.3 \%$ claimed they knew three, and $3.5 \%$ four, foreign languages.

\section{QUESTIONNAIRE FINDINGS}

The first question referred to students' preferences for the language(s) used in class: Should a course be carried out only in the "designated" language or not? ${ }^{6}$ Should English and Chinese be used in the Polish class? In an EFL course, is there any room for Chinese and other local languages? As it turned out, 70.6\% of the informants expressed their belief that only the target language needs to be applied. However, only $7.6 \%$ of them marked the highest score on the Likert sca1e. ${ }^{7}$ The same number totally disagreed with the idea. $64.3 \%$ were somewhere in the middle, with a majority of the cases suggesting that sticking to one language is the best.

When asked what is good about conducting classes purely in the target language, students pointed out that this is the best way to enhance and apply language skills. This aspect was mentioned by $48.6 \%$ of them, with $31.4 \%$ focusing specifically on speaking. $10.5 \%$ saw it as an invaluable opportunity to practice. $9.52 \%$

\footnotetext{
${ }^{6}$ The term originally used by Gorter and Cenoz (2011a, p. 340).

${ }^{7}$ A rating scale that includes five degrees that allow the respondents to express how much they agree or disagree with a given statement.
} 
wrote that non-mixed instruction helps to create the sort of environment in which one keeps growing and improving. The concept of providing favourable learning and working conditions is often mentioned in academic settings, where a great deal of attention is being paid to uniting the community and developing a strong sense of coherence.

$20 \%$ of the answers focused on the efficiency of studying in such a class, where knowledge will be accumulated much faster than expected. Other benefits included: boosting learner's confidence, quicker vocabulary acquisition, motivating intellectual challenge, anxiety reduction, promoting focus, or a chance for undertaking self-evaluation, as illustrated below:

a. Learn how Polish native speaker speaks.

b. By using only Polish in class, I can learn phrases and correct pronunciation.

c. It may strongly stimulate our English speaking and listening.

d. When we are learning English, the learning environment is very important. If we only speak English, we will improve without realizing it.

e. It helps me to think in Polish.

f. You are not afraid to speak English.

g. I can see how much I already know, what I got.

The next issue was how incorporating another language into the instruction would support learning the target language. In the case of the Polish course, English and Chinese had been used to facilitate acquisition. For the EFL learners, the language in question was Chinese. Here $56.2 \%$ of the answers pointed to the ease of understanding the content without much effort:

a. It's easier to understand some Polish words quickly.

b. Students can understand Polish words meaning more completely.

c. We can easily understand the word and we don't need to use the Google Translator.

d. Sometimes I don't understand what the teacher is talking about, for example, when teachers teach new vocabulary in English. For that situation, it is better to speak Chinese to me to understand new words.

e. It may reduce the chance of misunderstanding.

f. If there are some words we don't understand, we can use Chinese to translate. And we can know the meaning easily and correctly.

$18.1 \%$ thought that an additional language, when understood by all of the learners, would be used for the negotiation of meaning and some extra clarifications. It was "convenient" for $6.6 \%$ of the informants, this concept being of immense importance in Taiwanese culture, which values making life as easy and friendly as possible. Other answers included: saving time, promoting the feeling of familiarity, and conveying the meaning precisely. Some participants noticed that not all of their classmates were fluent enough to keep up and bilingual instruction prevented them from feeling excluded. For others, it was simply easier to polish their skills: 
a. Save time when explaining the meaning of new Polish vocabulary, understanding content easier.

b. Sometimes it's better to learn Polish grammar in English or Chinese, because I understand faster.

c. If you don't know some English words, you can ask the teacher. He/she will translate it for you.

d. If you get to know the meaning in your first language, you will remember it more.

e. Some students' English level is not very high. So, using both English and Chinese in class is good.

Among the in-class activities that should be carried out in the target language, the following dominated: "all" or "almost all" (these answers were given by $17.1 \%)$, instruction and games (13.3\% each), conversation practice (11.4\%), and vocabulary explanation $(10.5 \%)$. Other respondents suggested testing, reading and content analysis, and grammar instruction.

a. In my opinion, we can use Polish in class anytime, but I still prefer using both English and Polish when learning grammar.

b. I think everything can be done in Polish and that is how I learned Polish in Poland.

c. Most of the time in class. Because we can learn more foreign speaking.

d. I think they should speak/write in English all the time when they face the students. it might encourage students' English ability in a natural way.

Chinese (or Chinese along with English in Polish language classes) may be used mainly for: presenting and defining new words $(45.7 \%)$, whenever a thorough explanation is requested (14.2\%), grammar instruction (7.6\%), and clarification regarding the tasks and homework $(6.6 \%)$. Other ideas included: classroom management, roll call, games, eliciting students' knowledge and requesting feedback, small talk after class, and translations:

a. Learning vocabulary. We can exactly understand the vocabulary in native language and it will be easy.

b. When students really cannot understand the meaning of Polish words. Chinese would be best, but English also works.

c. I think they should use Chinese only when students have questions or the students will still rely on Chinese like always.

d. They should speak/write in Chinese when there are words we don't understand in English. Translating into Chinese would be easier and faster to understand.

e. If they use only English to introduce something and someone cannot get it, then the teacher may use Chinese to say the things again.

f. I think everything can be done in Polish, but if students have any questions that can't explain or understand well in Polish, then we should speak English.

g. When talking about Polish grammar and explaining homework and tests.

h. Polish grammar!!! 
How the students feel when the class is being conducted in the target language was another question. As the data analysis revealed, $62.1 \%$ of the respondents were positive about this experience. They saw it as a chance to practice and enhance their listening skills and pronunciation. Some of them reported that they needed to increase their focus, which was beneficial in many ways. For others it seemed "more professional" and the instructor provided a role model for them to follow:
a. Feel good. I'll try to figure out what the teacher is saying.
b. Very good. If it is $100 \%$ English, will be much better.
c. I feel good, because if they always speak English, let us practice listening and speaking.
d. I think it is necessary and I think it's good.
e. I feel happy, because I can learn more.
f. I feel very good because I love English more than other things.
g. I feel my English has improved.
h. I feel OK!!! I only have to translate English into Chinese.

Every fourth person, however, expressed an exactly opposite feeling. $25.3 \%$ of the responses expressed certain anxiety concerning single-language exposure. Some students found it hard to understand and overwhelming. They might have a hard time trying to keep up if the pace was too brisk. Others were afraid they could miss some snippets of information:

a. I feel very nervous, because I'm pretty sure that I can hardly understand the meaning in Polish.

b. Sometimes I don't know what the [Polish] teacher wants to express.

c. It could be hard for me to understand the situation when the [Polish] teacher is announcing something important.

d. Sometimes, when the teacher speaks fast, I will feel confused.

e. Sometimes I cannot understand what my teacher wants to tell us.

f. When he [the teacher] speaks fast and says a lot, I feel I can't follow the class.

g. Nervous, because scared to listen to difficult words.

h. I feel nervous because some words I don't understand and it will be hard to communicate.

i. I didn't listen and understand, maybe my English is very terrible.

$j$. Sometimes I don't pay attention to hear what the instructor says, because imagine that someone is speaking in the language you're not great at, it is tough to keep listening and focus.

k. If the time of course is long, it makes me a little tired. Because it is hard to listen to a foreign language for a long time.

$11.5 \%$ of the answers highlighted a certain degree of ambivalence. The students saw the benefits, and yet, they were aware of the downsides. There was always some "but" here:

a. Hard but interesting.

b. It is good to create an English-only environment, but I may miss some words. 
c. I feel Oh my God! Because I don't understand. But it's interesting.

d. A little difficult, but it can make me practice English listening.

Next, students were asked how they felt when their native language (or English, in Polish class) was used to accompany the instruction. Here, $76.4 \%$ of the informants were positive about it; every eighth person (13.4\%) was displeased with the idea. For others, it was normal, as they had got used to it over the course of education (I don't have any feeling because that's how I was taught when I was a kid.) Some learners thought it was easy, but not beneficial in the long term (I'm really happy to listen to Chinese, it can let you know what the teacher is talking about, but it may not help to learn another language meaning.) Now, let us briefly see the positive responses. Some students put stress on the amiability of the class in which one had no problem trying to grasp the meaning. Familiarity was seen as yet another merit:
a. I feel very nice because it can help me.
b. It is easy to understand, let me feel friendly.
c. Feel great. Because Chinese can be close to our mood.
d. It's good for me because if I don't know the word I can use Chinese to know the meaning.
e. I think it's good, because you can understand what the teacher says.
f. Not nervous, because I understand.
g. I will respect teacher's choice, maybe the teacher just wants to let the other students understand.

Not everyone, though, considers this solution feasible. Answers like those cited below shed a light on the problem:
a. I can't feel the magic energy of English!
b. I feel not good. If they always say Chinese words, we can't learn more about English.
c. I can understand but I don't think it's meaningful enough to learn this way.

Interestingly, $13.4 \%$ students submitted favourable comments on their instructor's effort to speak Chinese in class, a language that is foreign for her (It is funny and cute (no offence). My English teacher is adorable when the Chinese is not standard.)

To say that Chinese (sometimes used along with English, as in the Polish class) is the only local language used in class would be an oversimplification, for there is more to the story: Taiwanese, the language of family gatherings and communication on the streets. Considered vernacular by some, it remains a source of pride for those who want to retain their ethnic identity. One fourth of the students $(24.7 \%)$ noticed that their teacher would sometimes use it in class. Some (6.7\%) claim that it facilitates the process of learning (When they [instructors] are explaining a sentence or word, to help us better understand the meaning. or to explain a meaning more clearly than in Chinese.) The true colours are revealed when we see how strongly it is bound to the emotional aspect of life; Taiwanese will be 
used for telling jokes to bridge the gap between the instructors and students, for singing (with the professor as the performer), or for arousing students' interest and engagement. It may be heard when one is annoyed and chooses to vent anger.

Now, to get a clearer picture of the perceptions of translanguaging in a FL class, it may be helpful to see what activities would preferably be carried out by the learners in the target language. $26.3 \%$ of the responses suggested that students want use the language to answer teacher's questions. Other groups expressed their willing to practise their conversation skills $(20.2 \%)$ or to communicate with the instructor $(8.1 \%)$. One tenth (11.1\%) think the target language should be used for testing. 9.1\% would be glad to do "all" or "almost all" in the language they are trying to master (Except when learning grammar, all activities should or could be done in Polish.; I think almost everything, including saying Dzień dobry, Do widzenia; They [students] should speak/write in English all the time, but that's impossible.). At the same time, $6.1 \%$ might use it mainly for posting reports and writing homework assignments. Other responses suggested reading, taking notes, and watching videos.

When asked what activities they would be willing to carry out using Chinese (or Chinese and English), it is in the supporting language: most of the students mentioned small talk with their peers $(21.6 \%)$, negotiation of meaning $(21.6 \%)$, group discussions (20\%), and all the interactions that support the comprehension process, including asking for support and clarification or offering support to those who cannot follow the class $(18.5 \%)$. Other ideas included taking notes or reviewing grammar. Some answers emphasized the importance of Chinese in FL acquisition:

a. For me, I need English to help me understand the rules when learning Polish grammar.

b. When we do the research, we often use Chinese, because we think in Chinese.

c. When we don't know how to speak some English, then the teacher tells us that we can speak Chinese.

d. When teacher wants students to explain the words' meaning.

$5.7 \%$ of the students declared using Taiwanese in class, with their answers suggesting a similar attitude to that among the instructors: for fun or to vent spleen. "Joke" - was the shortest and most common answer. It could be used to discuss the meaning of the current content or relax:
a. Yes, anytime, because we are Taiwanese people.
b. Sometimes I may speak Taiwanese because I'm from Miaoli ${ }^{8}$. Speaking Taiwanese be- came my habit.
c. Sometimes I speak Taiwanese, make a joke to let my classmates laugh.
d. Yes, when I share some funny things with my friends.
e. When we are kidding or say a joke, we use Taiwanese.

\footnotetext{
${ }^{8}$ A county in Western Taiwan, populated mainly by people of Hakka and Taiwanese origin.
} 
f. Yes, because my family sometimes use it to communicate.

g. I speak Taiwanese when I'm very angry.

Most of the students, however, do not use it; their answers expose a degree of emotional distance from the language in question. In some cases, the individual's proficiency level remains an issue. It is also a question of the status the language holds: for many individuals, it is to be used only in private settings, shared only with household members and trusted friends. Others may avoid speaking it in public not to exclude those who may not be so fluent:

a. I don't, because my Taiwanese is very bad.

b. I don't know how to speak Taiwanese.

c. No, I speak Taiwanese only at home.

d. We say English and Chinese in class, because not everyone can use Taiwanese.

e. Seldom, because there are less people who speak Taiwanese at our age.

f. No, because some other people don't know Taiwanese.

g. No, I just talk in Taiwanese with my grandmother and the other family members.

h. Some persons can't speak Taiwanese, so we need to speak the language they understand.

One of the participants reported that she would talk to her mother in Tagalog, if she called during class.

The last set of questions referred to the particular language skills in Mandarin: Would they be of any use when one is mastering a foreign language? It turned out that many of the informants did not realize how their mother tongue might be applied in the process; their confusion was expressed while filling in the questionnaire or in the answers No idea! or No Way! A Polish learner wrote: It doesn 't help me. I think they are totally different things.

For those who were learning Polish, English and Russian could be applied as well, as they preceded it in the process of building up one's linguistic repertoire, as illustrated in the following cases: To me, my Polish and Russian degrees [of advancement] are similar. I am still a beginner in both. This way, it helps me a lot to distinguish and memorize. Here is one more instance: I found that there are some connections between Polish and Russian (or English). Thus, I sometimes use these languages when learning Polish.

$62.8 \%$ of the respondents saw some benefits of reading in Chinese about English/Polish. Facilitating comprehension was often pointed out as the main asset. $26.7 \%$ of the students revealed the importance of translation and understanding the full meaning of newly encountered words. The work could be done with the help of a dictionary or electronic translator. Mastering grammar would be easier as well (5.7\%). Others focused on reading Western novels in Mandarin, reading about American or Polish culture on line (also 5.7\%). Bilingual textbooks and magazines for EFL learners were sometimes mentioned, too. $2.4 \%$ of the students mentioned watching movies in English or Polish, but with Chinese subtitles. 
a. Easier to understand the content and learn Polish words.

b. It doesn't improve my fluency in Polish a lot, but can help me understand more about culture and grammar.

c. You can learn some words: When you're reading in Chinese, then you turn it into English.

d. Some textbooks explain the information in Chinese to let us get the point easier.

When putting pen to paper, jotting down the key points in class or before a test was mentioned by $15.2 \%$ of the informants. They would set down what the professor had written or said. Some subjects reported that this facilitates committing the material to memory. One in eight of them (12.4\%) responded that they would initially draft their own paragraph or essay in Chinese, and compose it in the target language later on. For $11.4 \%$, Mandarin was useful for copying down vocabulary definitions. Other replies included putting down grammar comments and explanations and planning one's own learning process. $8.6 \%$ of the students openly wrote that they had no clue how writing in Chinese may be applied.

a. It sometimes helps me to recall some Polish words.

b. If it's writing the translation down, then it can help us understand it, the logic and how to use it.

c. You can translate your writing into English.

d. Writing in Chinese (together with English), I will remember it better.

e. When I'm taking notes, I usually write down both in English and in Chinese. It can help me remember the meaning.

When it comes to listening in Chinese, again, the dominating majority of the respondents had no idea how it would support them or expressed their conviction that it is of no use. $15.2 \%$ would see it as an opportunity to practise their interpretation skills, an occasion to challenge themselves and try to express what has been heard in the target language. Listening to the lecturer's explanations was mentioned by $7.6 \%$ of the respondents. $3.3 \%$ would set English subtitles when watching a Taiwanese movie. Some found certain similarities between the phonemes of their mother tongue and English. Some of the Polish language learners wrote that it would be recommendable to compare the language to Russian, which they are already fluent in. Improving one's overall listening skills was mentioned as just another advantage: If you know how to listen when the speaker is expressing themselves in Chinese, you will easily apply this ability into the situations when English/Polish is being spoken.

a. If some Polish and English words are similar, I can guess the meaning, but Slavic languages are more helpful than English.

b. I think English listening sometimes helps me to improve my Polish. Because none of the languages is my mother tongue. It helps my brain to think in other ways.

c. While listening, you can think how fast you can translate it into English.

d. You can absorb different thinking. 
In terms of speaking Mandarin and how it may support FL learning, 8.6\% of the respondents saw it as a way of enhancing one's interpreting competence. It may be used for interacting with the teacher and asking additional questions, especially when the individual lacks confidence to express themselves in the target language (again, 8.6\%). Another $6.7 \%$ of the respondents thought it may be immensely helpful when the student is trying to negotiate the meaning of a new vocabulary item. Several people saw its value in promoting one's own overall communicative competence; for them, the ability to verbalize one's thoughts in the mother tongue was a necessary condition to master speaking in the target language. The same was true for English: one subject reported that overcoming his difficulties in speaking it motivated him to improve his Polish. Speaking in Chinese (or English, in Polish class) may be a lifeline, too, when you are by no means able to express yourself in the target language, but you need help. It is worth noticing that some students believe that in Mandarin they can be far more creative, so at the stage of planning an assignment, it is far more beneficial to speak it. It may be also used for elaborating a sentence before it is ready to be expressed in the FL. Some other responses included: adding an element of familiarity to the learning process, which works pretty well for those who tend to feel anxious, explaining the newly acquired knowledge, analysing borrowings and comparing two languages, asking for clarifications, or in-class discussion.

a. Even though I can't speak Polish well, I like to ask my teacher about translating English phrases into Polish.

b. I can normally speak English in my daily life and it helps me to speak Polish just like "another English". I will not feel shy or scared.

c. We can pre-organize the sentence in Chinese, then think into English.

d. It helps me understand how to correctly use Polish words and grammar.

e. Speaking ability in Chinese can influence your English skills.

f. Some words sound exactly the same in English, for example: chocolate.

g. Yes, it helps. When I still have problems with Polish, I will ask my classmates in Chinese.

h. When I have a question, I ask the teacher, then the teacher answers and lets me know the meaning.

Table 1. Summary of answers

\begin{tabular}{|c|c|c|c|}
\hline Reading & Writing & Listening & Speaking \\
\hline $\begin{array}{l}\text { 1. understanding } \\
\text { the vocabulary } \\
\text { meaning; } \\
\text { 2. translation; } \\
\text { 3. improving } \\
\text { grammar; }\end{array}$ & $\begin{array}{l}\text { 1. taking notes; } \\
\text { 2. copying down from } \\
\text { the whiteboard; } \\
\text { 3. setting down in } \\
\text { order to remember; } \\
\text { 4. drafting a } \\
\text { composition; }\end{array}$ & $\begin{array}{l}\text { 1. improving one's } \\
\text { interpretation skills; } \\
\text { 2. listening to the } \\
\text { instructor; } \\
\text { 3. watching a } \\
\text { Taiwanese film with } \\
\text { English subtitles; }\end{array}$ & $\begin{array}{l}\text { 1. improving one's } \\
\text { interpretation skills; } \\
\text { 2. interacting with the } \\
\text { teacher; } \\
\text { 3. asking questions; }\end{array}$ \\
\hline
\end{tabular}


Table 1. (cont.)

\begin{tabular}{|c|c|c|c|}
\hline Reading & Writing & Listening & Speaking \\
\hline $\begin{array}{l}\text { 4. reading books } \\
\text { originally written } \\
\text { in the target } \\
\text { language; } \\
\text { 5. exploring the } \\
\text { target culture; } \\
\text { 6. bilingual } \\
\text { publications; } \\
\text { 7. movies with } \\
\text { Chinese subtitles. }\end{array}$ & $\begin{array}{l}\text { 5. writing down } \\
\text { vocabulary } \\
\text { explanations; } \\
\text { 6. adding grammar } \\
\text { comments; } \\
\text { 7. planning one's own } \\
\text { learning process. }\end{array}$ & $\begin{array}{l}\text { 4. comparing sounds; } \\
\text { 5. training one's } \\
\text { general ability to } \\
\text { listen. }\end{array}$ & $\begin{array}{l}\text { 4. promoting } \\
\text { one's overall } \\
\text { communicative } \\
\text { competence; } \\
\text { 5. requesting help; } \\
\text { 6. planning a project } \\
\text { or a sentence at the } \\
\text { initial stage; } \\
\text { 7. adding familiarity. }\end{array}$ \\
\hline
\end{tabular}

Source: own study

Last, but not at least, are students aware of how thinking in their mother tongue could be applied? Here, again, the answers show different opinions, as expressed in the following examples:

1. Logic in Chinese doesn't help [to improve Polish]. English may be better.

2. Thinking in Chinese helps me to improve, because it would force me to think in another language. After that, it will be easier to think in Polish because I'm not limited to Chinese thinking way.

3. I feel like it's the only way till this moment for me to totally understand Polish grammar rules.

4. It helps me understand Polish and how to use it.

\section{CONCLUSIONS}

As we can see, seven out of ten participants expressed their belief that monolingual practices ought to dominate FL instruction. However, only seven per cent would like to see only the target language being utilized. What this means in practice is that for the majority of the participants, there was room for various instances of bilingualism in the educational setting. This is in agreement with the current tendency towards "communicating with all students and negotiating challenging academic content with all of them by building on their different language practices, rather than simply promoting and teaching one or more standard language" (Garcia, Sylvan 2011, p. 386). They were aware of the numerous merits offered by this approach, with quick and efficient acquisition progress being the main benefit. Deploying diversified linguistic resources, however, seemed to be much more appealing, as they offer access to deeper comprehension and easier self-expression. Among the most desirable EFL/PFL activities, students listed instruction, games, 
conversation practice, and negotiation of meaning. In practice, it opens the door to positioning students as so-called language brokers - capable and well-informed individuals, actively contributing to the learning process (Palmer et al, 2014, p. 760). Vocabulary and grammar explanations and extra clarifications were usually mentioned as tasks to be performed in Chinese (EFL) or Chinese, English, and Russian (for Polish learners). The latter group may accrue measurable benefits from learning cognates, the understanding of which facilitates word recognition, as well as aural and written comprehension (Baird et al., 2016, p. 448). ${ }^{9}$

More than $60 \%$ of the participants reported harbouring positive feelings about classes held in the target language, as it would enable them to promote their speaking and listening skills and increase their focus. One quarter of the responses, however, revealed quite opposite attitudes: anxiety and the inability to follow and keep up could be an issue. Additionally, around $10 \%$ of the informants expressed rather ambivalent views. Three quarters of the students would welcome their native language (or English in the PL education context) as a means of FL instruction and "a source of communicative support", as noted by Gorter and Cenoz (2011, p. 444), while one in eight people wrote they did not want it. For some, amiable and inclusive, for others, the practice seems to decrease the chances of success. Overseas instructors can feel free to speak Mandarin in class; their efforts would meet students' understanding and friendly responses. Although not very often, some teachers speak the Taiwanese language in the classrooms; this would be done for providing clearer explanations or building up a rapport with students. Giving vent to one's emotions in Hokkien may be sometimes observed.

Among the activities that students would gladly conduct in the target language, answering questions and interactions with the instructor dominated. Small talk with peers, negotiation of meaning, along with group discussion would be welcome in Chinese (together with English in the PL class). Hoklo would be sometimes used for bonding with peers, unless they are not fluent in it. It is so because in a society that values overall cohesion, exclusion needs to be avoided. Hokkien may be used for joking or expressing emotions. Many, however, do not speak it, due to their low proficiency level or a conviction that it is to be used in private. Finally, it was not uncommon for Taiwanese FL learners to demonstrate little awareness of how employing particular skills in Chinese (paired with English if considering PL instruction) can facilitate target language acquisition. Those who saw possible applications focused on vocabulary, translation/interpretation, and grammar. Some of them mentioned listening to and interacting with the teacher.

${ }^{9}$ Baird at al. (2016, p. 450) use the term cognate facilitation effect to denote the advantage of bilingual learners over their monolingual peers. 


\section{DISCUSSION}

It is, then, justified to conclude that most of the Taiwanese FL learners who participated in the study, $92.4 \%$ to be precise, did not expect the exposure to be monolingual, for many reasons. They do see its potential merits, but they apparently prefer to stay in their comfort zone, without stretching too much and too often. They seem to be quite comfortable with the bilingual approach to didactics and the opportunities it offers, for it guarantees better access to the curriculum and facilitates the transmission of knowledge. At the same time, the results of empirical studies show that there is no advantage in favour of single-language exposure (Anton et al., 2016, p. 43). Breaking the one-subject-one-language principle by alternating languages has been proven to exert no harmful effects.

At the same time, as the Readers may have noticed, some of the answers, diversified as they are, can appear to be mutually exclusive. In practice, this means that within one class, a teacher may face individuals with totally different needs and expectations. Some will openly prefer to have vocabulary defined only in the target language and perceive Chinese explanation as a waste of time. Since they pay for it, even in the public education sector, their feedback needs to be taken into consideration, especially as once in a semester, students officially evaluate their professors. In the same room, however, there will be people who need slower and more attentive instruction supported by numerous comments (or at least summary) in Mandarin. It may be, thus, rather impossible to satisfy everyone and there is probably no point in trying to do so. Wisdom is situational, as they say, and a certain degree of flexibility can help to adjust to a particular educational context. Varying instruction methods, at the individual level, and diversified staff at the institutional one are recommended.

From the author's own teaching experience, purely monolingual instruction causes a great deal of anxiety among learners who often do not really know what they are expected to do and what is being said. Pleasant memories from a summer camp in Poland are one thing, but the down-to-earth reality of the classroom, where certain activities have to be done to fulfil the requirements, is something else. Do not be misled by the lack of opposition to your way of teaching, for students will avoid face-to-face confrontations and they will still keep smiling to cover their confusion. On the other hand, this situation offers a wonderful opportunity for bilingual practices to be deployed and the teacher can serve as the best role model for it, using a whole range of linguistic resources to express themselves joyously and efficiently. Most students usually accept it and show positive reactions.

In Taiwanese society, collectivism is highly valued. Thus, multiple responses demonstrating the student's care for the comfort of the interlocutors and their sensitivity to the sociopragmatic variable (see Cenoz, Gorter, 2011a, p. 443). Avo- 
iding exclusion at all costs is preferred. What deserves attention is the obvious tendency to be very selective when choosing the means of expression: speaking Taiwanese will be avoided if a classmate is not fluent in it. For many, it will be the language of personal bonds and emotions. It is, thus, not uncommon for the locals to speak it only with their relatives in order to proudly emphasize the depth of the connection. Others may regard it as vernacular and avoid speaking it in public, considering Chinese superior. (The latter may still come with different accents, so that the so-called mainlanders, i.e. the children of the 1949-immigrants, can be easily distinguished from those whose ancestors arrived much earlier.) Linguistic competence equals being aware of when and where to use particular words and standards. Language, thus, transforms in different settings and in relation to other codes acquired by the particular user (Davila 2020, p. 33). As pointed out by Otheguy etal. (2015, p. 297), the more complex your personal linguistic resources, the more challenging decisions you ought to take. In fact, a person hardly ever deploys different languages in the very same ways to the very same degree. They rather need to use them according to their current communicational needs and such choices may turn out to be rather complex (Cenoz, Gorter 2011a, p. 340), often balancing between diametrically different ideologies and policies (Canagarajah 2011, p. 416). Therefore, bilinguals should not be treated as inferior to monolinguals. In fact, they have a more diversified communication arsenal and should be actively encouraged to present it.

It may be surprising how few people are actually aware of the ways in which the languages they have acquired earlier can help them to master a new one: certain skills or bits of information may be successfully transferred and there is no need to teach them from scratch (Gorter, Cenoz 2011, p. 444). ${ }^{10}$ As teachers, we may actively promote this consciousness and equip our students with some know-how, which may translate into a greater success and satisfaction rate. A safe space for multilingual practices should be created. However, generalizations in search for a one-size-fits-all strategy, as Canagarajah (2011, p. 415) puts it, ought to be avoided. As suggested by Garcia and Sylvan (2011, p. 386), our educational practices should reflect contemporary dynamics of the globalized world and people living in it and "rather than constructing educational models for a particular type of student who uses one language or the other, we must learn to focus on teaching individuals within multilingual classrooms in which the plurality is created by paying attention to the singularity of a particular student" (ibid.). Various, individually tailored techniques may turn out to be very useful and encouraging. Inspired and motivated learners are, at the end of the day, what we want.

${ }^{10}$ Cenoz and Gorter (2011b) further elaborate the problem of writing skills transfer, showing a clear relationship between different dimensions including content, structure, vocabulary, grammar, and mechanics, proving that students who achieve good results in one language are more successful at becoming efficient writers in another one. 


\section{BIBLIOGRAPHY}

Anton, E. et al., 2016, Testing Bilingual Educational Methods: A Plea to End the Language-Mixing Taboo, "Language Learning", issue 66:2, pp. 29-50, https://onlinelibrary.wiley.com/doi/ abs/10.1111/lang.12173.

Baird, A., Palacios, N., Kibler, A., 2016, The Cognate and False Cognate Knowledge of Young Emergent Bilinguals, "Language Learning", issue 66:2, pp. 448-470, https://onlinelibrary.wiley.com/doi/abs/10.1111/lang.12160.

Busse, V. et al, 2019, Addressing Linguistic Diversity in the Language Classroom in a Resource-Oriented Way: An Intervention, Study With Primary School Children, "Language Learning", issue: 70:2, pp. 1-38, https://onlinelibrary.wiley.com/doi/full/10.1111/lang.12382.

Canagarajah, S., 2011, Codemeshing in Academic Writing: Identifying Teachable Strategies of Translanguaging, "The Modern Language Journal", issue 95/3, pp. 401-417, https://onlinelibrary.wiley.com/doi/abs/10.1111/j.1540-4781.2011.01207.x.

Cenoz, J., Gorter, D., 2011a, A Holistic Approach to Multilingual Education: Introduction, "The Modern Language Journal”, issue 95/3, pp. 339-343, https://onlinelibrary.wiley.com/doi/abs/10.1111/j.1540-4781.2011.01204.x.

Cenoz, J., Gorter, D., 2011b, Focus on Multilingualism: A Study of Trilingual Writing, "The Modern Language Journal", issue 95/3, pp. 356-369, https://onlinelibrary.wiley.com/doi/abs/10.1111/j. 1540-4781.2011.01206.x.

Creese, A., Blackledge, A., 2010, Translanguaging in the Bilingual Classroom: A Pedagogy for Learning and Teaching?, “The Modern Language Journal”, issue 94/1, pp. 103-115.

Davila, L., 2020, Multilingual Interactions and Learning in High School ESL Classrooms, "TESOL Quarterly", vol. 54, no. 1, pp. 30-55.

Eberhard, D.M., Simons, G.F., Fennig, D. (eds.), 2020, Ethnologue: Languages of the world, 23rd edition, https://www.ethnologue.com [28.05.2020].

Garcia, O., Sylvan, C., 2011, Pedagogies and Practices in Multilingual Classrooms: Singularities in Pluralities, “The Modern Language Journal”, issue 95/3, pp. 385-400, https://onlinelibrary. wiley.com/doi/abs/10.1111/j.1540-4781.2011.01208.x.

Garcia, O., Wei, L., 2014, Translanguaging: Language, Bilingualism, and Education, New York, Palgrave.

Gorter, D., Cenoz, J., 2011, A Multilingual Approach: Conclusions and Future Perspectives: Afterword, "The Modern Language Journal", issue 95/3, pp. 442-445, https://onlinelibrary.wiley. com/doi/abs/10.1111/j.1540-4781.2011.01203.x.

Holmen, A., 2019, Translanguaging pedagogy, in: Handbook of Pragmatics. 22nd Annual Installment, Jan-Ola Ostman, Jef Verschueren (eds.), pp. 49-58, https://www.org/10.75/ hop.22.tra3.

Lai, Y., 2009, Language Learning Strategy Use and English Proficiency of University Freshmen in Taiwan, "TESOL Quarterly", vol. 43, no. 2, pp. 255-280.

McKinney, C., 2017, Language and Power in Post-Colonial Schooling. Ideologies in Practice, New York and London.

National Statistics. Republic of China, Taiwan, 2020, https://eng.stat.gov.tw/point.asp?index=9, https://eng.stat.gov.tw/public/Data/7113143851PNHSNJPU.pdf [03.03.2020].

Otheguy, R., Garcia, O., Reid, W., 2015, Clarifying translanguaging and deconstructing named languages: A perspective from linguistics, "Applied Linguistics Review”, issue 6, pp. 281-307, https://www.degruyter.com/view/journals/alr/6/3/article-p281.xml.

Palmer, D., Martinez, R., Mateus, S, Henderson, K., 2014, Reframing the Debate on Language Separation: Toward a Vision for Translanguaging Pedagogies in the Dual Language Classroom, “The Modern Language Journal", issue 98/3, pp. 757-772, https:/experts.colorado.edu/ display/pubid_224764. 
Price, G., 2014, English for all? Neoliberalism, globalization, and language policy in Taiwan, vol. 43, issue 5, pp. 567-589, https://www.cambridge.org/core/journals/language-in-society/ article/abs/english-for-all-neoliberalism-globalization-and-language-policy-in-taiwan/9EE5 C9AF- 7FB6E90F644BFFF0615EB9CE.

Price, G., 2019, Language, Society, and the State: From Colonization to Globalization in Taiwan, Boston and Berlin.

Rader, D., 2017, Teaching and Learning for Intercultural Understanding. Engaging Young Hearts and Minds, New York and London.

Wang, H. , Chang, S., 2002, The Commodification of International Marriages: Cross-Border Marriage Business in Taiwan and Viet Nam, "International Migration", issue 40(6), pp. 93-116, https://onlinelibrary.wiley.com/doi/abs/10.1111/1468-2435.00224.

Willey, T., Garcia, O., 2016, Language Policy and Planning in Language Education: Legacies, Consequences, and Possibilities, "The Modern Language Journal", issue 100, pp. 48-63, https:// onlinelibrary.wiley.com/doi/abs/10.1111/modl.12303.

Woodley, H., 2016, From Pain to Healing in Language Teacher Education, "The Modern Language Journal", issue 100, pp. 570-573, https://onlinelibrary.wiley.com/doi/abs/10.1111/ modl.4_12337.

Natalia Tsai

\section{POLSKI JAK „KOLEJNY ANGIELSKI”: POSTRZEGANIE TRANSJEZZYCZNOŚCI I INNYCH PRZEJAWÓW BILINGWALIZMU PRZEZ TAJWAŃSKICH STUDENTÓW UCZĄCYCH SIĘ JĘZYKA ANGIELSKIEGO ORAZ JEZZYKA POLSKIEGO}

Słowa kluczowe: transjęzyczność, dwujęzyczność, wielojęzyczność, Tajwan, język angielski jako obcy, język polski jako obcy

Streszczenie. Celem niniejszego artykułu jest przedstawienie tego, jak tajwańscy studenci uczący się języka angielskiego i języka polskiego postrzegają transjęzyczność oraz inne przejawy bilingwizmu na lektoratach. Zgromadzone dane pochodzą z analizy ankiety. Odpowiedzi wskazują na wyraźną przychylność wobec pomysłu posługiwania się wyłącznie językiem docelowym, jednak jedynie 7\% uczestników badania wyraziło jednoznaczne przekonanie co do tego, że takie rozwiązanie jest najkorzystniejsze. Ponad 90\% skłaniało się ku temu, aby w klasie używać przynajmniej dwóch języków. Zwiększenie skuteczności procesu nauki oraz wspieranie zdolności mówienia i rozumienia ze słuchu wymieniane były jako główne zalety podejścia monolingwalnego. Z drugiej zaś strony praktyki bilingwalne postrzegane są jako te, które ułatwiają dogłębniejsze zrozumienie tematu i wyrażenie własnych myśli. W artykule wyliczono też szereg zadań, które, zdaniem studentów, warto wykonywać wyłącznie w języku docelowym, oraz tych, których chętniej podjęliby się oni w języku rodzimym. Jak wynika z przedstawionej analizy, najkorzystniejszym rozwiązaniem może okazać się taki styl nauczania, który cechuje się pewną elastycznością i łączy w sobie rozmaite techniki pracy na lekcji. 